\title{
The In Sacco Dry Matter and Organic Matter Degradability of Four Feedstuffs
}

\author{
Pamungkas $\mathrm{D}^{1}$, Utomo $^{2}$ \\ ${ }^{1}$ Indonesian Beef Cattle Research Station \\ Jl. Pahlawan No. 2, Grati, Pasuruan 67184, East Java, Indonesia \\ ${ }^{2}$ Faculty of Animal Husbandry University of Gadjah Mada \\ Jl. Fauna No. 3, Bulaksumur, Yogyakarta 55281, Indonesia \\ dpamungkas2000@yahoo.com
}

\begin{abstract}
The degradability characteristic of four feedstuffs was examined in order to optimize the use of feedstuff to make a complete feed. Arenga waste (Aw), dried-Cassava waste $(\mathrm{dCw})$, dried Leucaena leaves $(\mathrm{dLl})$, and Commercial feed (Cf) as control were tested by in sacco method. The method consisted of preparation, incubation, and post-incubation. Four samples of respective stuffs were placed in nylon bag and incubated for $0,3,6,9,12,24,36$, and 72 hours (h) in the rumen of three fistulated cows ( $\mathrm{I}_{3}$ aged, female Ongole Crossbred, $250 \mathrm{~kg}$ of live weight). Each sample was represented by three replicates at each incubation time. The in sacco measurement using the equation of $\mathrm{D}=\mathrm{a}+\mathrm{b}\left(1-\mathrm{e}^{\mathrm{ct}}\right)$. The value of fraction $\mathrm{a}, \mathrm{b}$ and $\mathrm{c}$ were used to calculate the Effective Degradability (ED) with assumption that the outflow of feed particle size of rumen (Kp) was constantly at 0.06 . The data were analyzed by completely randomised design. Results revealed within $24 \mathrm{~h}$ incubation, the dry matter degradability (DMD) of $\mathrm{dCw}(79.50 \%)$ and $\mathrm{Cf}(70.68 \%)$ were higher than that of Aw (48.84\%) and dLl (54.44\%). Within 3-12 h of interval incubation, all materials were the same condition in the rate of loss dry matter with ranged 0.81 to $1.25 \mathrm{per} h$ and tended to decrease after 24-72 h interval incubation. Meanwhile the dry matter ED 0.06 of Aw (33.08\%) was the lowest and Cf (59.99\%) was the highest. As of $24 \mathrm{~h}$ incubation, the organic matter degradability (OMD) of $\mathrm{dCw}(62.97 \%)$ and $\mathrm{Cf}(64.37 \%)$ were higher than that of $\mathrm{Aw}$ (37.59\%) and $\mathrm{dLl}(45.09 \%)$. Within $24-72 \mathrm{~h}$ of interval incubation, all materials were the same condition in the rate of loss organic matter with ranged 0.09 to $0.18 \%$ per h. The organic matter TD 0.06 of $\mathrm{Cf}(62.28 \%)$ was the highest followed by dCw (46.58\%), $\mathrm{dLl}(42.44 \%)$, and $\mathrm{Aw}(25.45 \%)$. It can be concluded that the effective dry matter degradability of dried-Cassava waste $(\mathrm{dCw})$, dried-Leucaena leaves was lower than commercial feed (Cf, P>0.05) but they were higher than that of Arenga waste (Aw). This condition was also alike with their effective organic matter degradability
\end{abstract}

Key Words: Degradability, Feedstuff, In Sacco

\section{INTRODUCTION}

One key of successful farmer in raising beef cattle is to make the feed efficient, especially to reduce feed cost. In order to accomplish this, farmers should be offered by the option to choose available, abundant, and cheap feedstuff. This option is pointed out to utilize crop residues and or agroindustrial byproduct beside the forages. However, the weakness of crop residues as feed is generally less palatable, low degradability and low in nutrient content. Feedstuff from agricultural wastes or legumes straw was high in cell wall and low in nitrogen content or inbalance, therefore, the digestibility was low (Soeharto 2004; Ginting 2005) and these characteristics will inhibit feed intake.

All masticated, regurgicated and ensalivated of feedstuff were hydrolyzed to the simple component or it was anaerobic degradability (fermented) in the rumen and later absorbed in the intestinal tract. The level of feed degraded in the rumen was to synchronize nutrient avalibility to enhance microbial protein synthesis and nutritional usage directly for 
animal (host). The degradation rate of feedstuff was various and it depended on the level of synchronization and degradation in rumen. There was complexity in energy source and protein source of feedstuff used by ruminant but this relationship was important in utilizing nitrogen and energy (Biricik et al. 2006).

Determining the degradation rate of feedstuff of animal nutrient in regards to in sacco degradability (Utomo et al. 1999) was the aim of this experiment. The rate of degradability carbohydrate and protein of feed in the rumen gave the big impact in end product of fermentation and animal peformances.

\section{MATERIAL AND METHODS}

The feedstuff used as materials were Arenga waste (Aw), dried-Cassava waste $(\mathrm{dCw})$, dried Leucaena leaves $(\mathrm{dLI})$, and Commercial feed $(\mathrm{Cf})$ as control were respectively tested by the in sacco methods. Four samples of respective stuffs were placed in nylon bag and incubated at $0,3,6,9,12,24,36$, and $72 \mathrm{~h}$ in the rumen of three fistulated cow (I3 aged, female Ongole crossbred, $250 \mathrm{~kg}$ of live weight). The in sacco measurement using the equation of $\mathrm{D}=\mathrm{a}+\mathrm{b}\left(1-\mathrm{e}^{\mathrm{ct}}\right)$. Furthermore the value of fraction $\mathrm{a}, \mathrm{b}$ and $\mathrm{c}$ were used to count the Effective Degradability (ED) with the assumption that the movement of feed particle size out of rumen $(\mathrm{Kp})$ was constantly at 0.06 ; according to the equation of $\mathrm{ED}=\mathrm{a}$ $+(\mathrm{b} \times \mathrm{c}) /(\mathrm{c}+0.06)$. Bags corresponding to the longest incubation time were inserted first and followed by the other bags in sequentially decreasing time (Ørskov 1982; Osuji et al. 1993; Newman et al. 2002). This was to ensure that all the bags were withdrawn at about the same time. On withdrawal of the bags from the rumen, they were washed under running tap water until the rinse water was clear and the bag-attached microbe contamination assumed to have reduced to the barest minimum. At the end of rinse, the bags were then dried at $65^{\circ} \mathrm{C}$ for $48 \mathrm{~h}$ to a constant weight to determine rumen residue DM content. The washing loss at zero hour was the loss due to non-incubation, for both the DM and OM components. Samples of the test materials were soaked in warm water (approx. $37^{\circ} \mathrm{C}$ ) for one hour followed by washing and drying as done with the residues from incubation. Dry matter and OM losses were calculated as the difference in weight between the pre-incubated and post-incubation samples and expressed in percentage. The weight data gathered were subsequently analyzed using the NEWAY computer program for estimating degradability constants, by fitting them into the non-linear equation $\mathrm{P}=\mathrm{a}+\mathrm{b}$ $\left(1-\mathrm{e}^{\mathrm{ct}}\right)$ of McDonald (1981) where $\mathrm{P}$ is the potential degradation of the nutrient components under investigation after time ' $t$ ', ' $a$ ' the water soluble fraction, ' $b$ ' the insoluble but rumen degradable fraction and ' $c$ ' the rate of degradation of the rumen degradable fraction ' $b$ '. In order to confirm the rate of constant degradability (value of $c$ ), the lost of dry matter and organic matter percentage was determined by counting the loss of dry and organic matter at 3-12 h and 48-72 $\mathrm{h}$ of incubation. The data were analyzed by Completely Randomised Design.

\section{RESULTS AND DISCUSSION}

\section{Dry matter degradability}

The data of in sacco dry matter degradability (DMD) of respective feedstuff were shown in Figure 1. Within 3 to $72 \mathrm{~h}$ of incubation, there was a significant difference in degradability with a similar pattern of dry matter loss. Until $24 \mathrm{~h}$ of incubation the DM loss of $\mathrm{dCw}$ and $\mathrm{Cf}$ were 79.50 and $70.68 \%$. It reflected that these stuffs represent highly degraded materials as energy source and high degraded protein source in the rumen. If we 
compared to the chemical composition (Table 1), the highly degraded $\mathrm{DMD}$ of $\mathrm{dCw}$ was related to the low of NDF, $\mathrm{ADF}$, and $\mathrm{CF}$. By means, the low cell wall composition in the materials allowed microbes to attach and digest the feed easily. The washing loss of each feedstuff was different so their starting point of degradability was different as well.

Table 1. Chemical composition of feedstuff (\% DM basis)

\begin{tabular}{lcccccccc}
\hline \hline Feedstuff & DM & OM & CP & C Fat & NDF & ADF & Ca & P \\
\hline Aw & 92.30 & 97.40 & 5.70 & 2.40 & 63.40 & 33.50 & 0.69 & 0.15 \\
dCw & 86.80 & 98.40 & 3.40 & 1.30 & 13.40 & 9.30 & 1.15 & 0.11 \\
dLl & 90.10 & 82.80 & 22.40 & 4.80 & 38.90 & 30.30 & 0.95 & 0.20 \\
Cf & 93.10 & 91.10 & 23.00 & 1.80 & 24.90 & 16.90 & 1.77 & 0.70 \\
\hline
\end{tabular}

Result analysis from Nutrition Laboratory of Beef Cattle Research Station; Aw: Arenga waste; $\mathrm{dCw}$ : dried Cassava waste; dLl: dried Leucaena leaves; Cf: Commercial feed

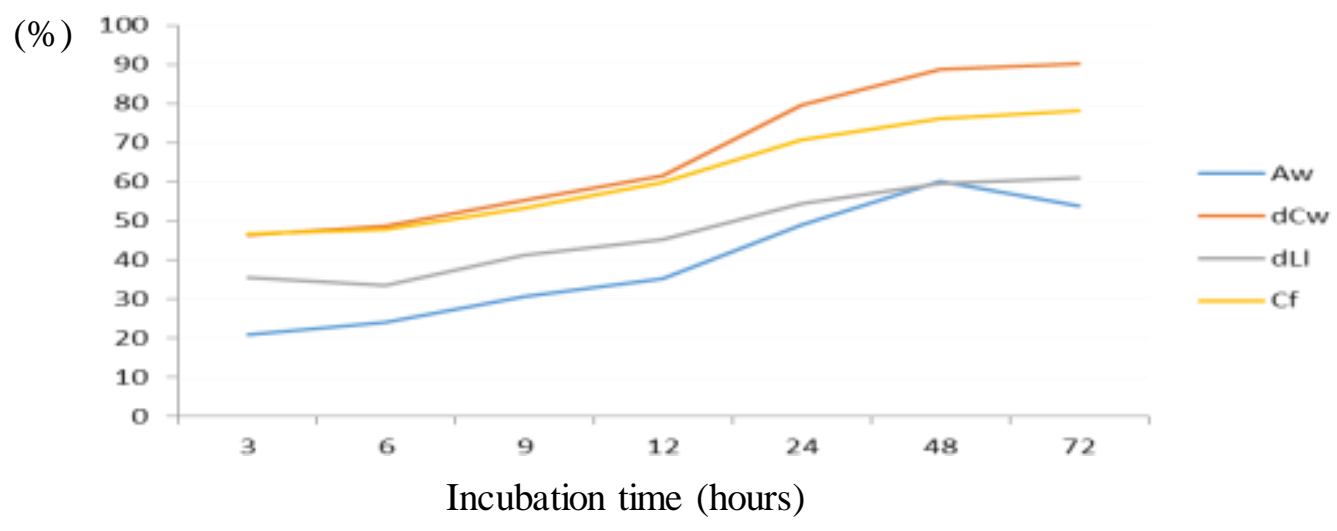

Figure 1. In sacco dry matter degradability of feedstuffs during 72 hours incubation

Table 2. Dry matter loss percentage at two level interval incubation of feedstuff $(\% / \mathrm{h})$

\begin{tabular}{lcc}
\hline \hline \multirow{2}{*}{ Feedstuff } & \multicolumn{2}{c}{ Interval of incubation (h) } \\
\cline { 2 - 3 } & $3-12$ & $24-72$ \\
\hline $\mathrm{Aw}$ & $1.19 \pm 0.23$ & $0.23 \pm 0.14$ \\
$\mathrm{dCw}$ & $1.25 \pm 0.31$ & $0.22 \pm 0.07$ \\
$\mathrm{dLl}$ & $0.81 \pm 0.27$ & $0.11 \pm 0.01$ \\
$\mathrm{Cf}$ & $1.09 \pm 0.34$ & $0.16 \pm 0.08$ \\
\hline
\end{tabular}

The highest DM loss percentage at 3-12 $\mathrm{h}$ occurred in substrate $\mathrm{dCw}(1.25 \% / \mathrm{h})$, followed by Aw $(1.19 \% / \mathrm{h})$, Cf $(1.09 \% / \mathrm{h})$ and $\mathrm{dLl}(0.81 \% / \mathrm{h})$. The DM loss percentage of feedstuff in this research was higher than those of report on coffee pods, corn ear, and the mix of coffee pods and corn ear (Pamungkas 2011) which ranged 0.44 to $1.09 \% / \mathrm{h}$ (at 3-12 $\mathrm{h}$ incubation). This conditon was influenced by the chemical composition, especially the content of crude protein (CP) and neutral detergent fiber (NDF). As of fiber and proximate analysis (Table 1), there was indication that feedstuff containing high $\mathrm{CP}$ (Cf and $\mathrm{dLI}$ ) showed the higher DM loss percentage. Within 24 to $72 \mathrm{~h}$ of incubation, there was a decrease DM loss percentage. We found that the highest DM loss percentage was $\mathrm{dCw}$ and the lowest was $\mathrm{dLl}$. The high $\mathrm{DM}$ loss percentage of $\mathrm{dCw}$ was related to the high content of non structural carbohydrates known as amylum. Meanwhile NDF content in $\mathrm{dCw}$ was low (13.4\%) compared other stuff, so microbial rumen especially amylolytic bacteria grew and developed, and therefore enzyme was produced fast and digested $\mathrm{dCw}$ substrates. 
Data of DM degradation characteristicistic of feedstuff were shown in Table 3. It showed that the fraction a of $\mathrm{dCw}, \mathrm{dLl}$, and $\mathrm{Cf}$ were same (ranged 31.35 to $40.92 \%$ ) but they were higher than those on Aw (15.65\%). It meant the solubility of Aw was the lowest and this was related to the high of NDF $(63.40 \%)$. Meanwhile the fraction $b$ was range 33.28 to $58.58 \%$. The highest of fraction $\mathrm{b}$ was found in $\mathrm{dCw}(58.58 \%)$, followed by $\mathrm{Aw}$ (45.95\%), Cf (38.33\%) and dLl TDL (33.28\%). The low of degradation potential was affected by the high component of plant cell wall. Although the CP of dLl was high (22.4\%) and nitrogen may be bounded in the cell wall causing extra times are required by rumen microbesto degrade the cell wall. Therefore, potential degradation of dLl becomes low. Moreover, the rate of degradation potential (fraction c) of each feedstuff was not significantly different. All substrates were not in the maximum degradation. This was due to the value of fraction $(\mathrm{a}+\mathrm{b})$ was higher over DM loss percentage at $72 \mathrm{~h}$ incubation, as followed: $\mathrm{Aw}(61.59 \%$ vs $60.08 \%)$, dCw (96.30\% vs $90.21 \%)$, dLl (64.62\% vs $61.06 \%)$, and $\mathrm{Cf}(79.25 \%$ vs $78.14 \%)$. This finding was supported by data of effective degradability (ED, Kp 0.06) which vary from 33.08 to $59.99 \%$ (as shown in Table 3). Meanwhile Ikhimioya et al. (2005) reported that the ED of DM decreased with increase in outflow rates ranging from a low of $35.88 \%(\mathrm{k}: 0.05)$ to $72.67 \%(\mathrm{k}: 0.02)$ in the leaves and $26.59 \%$ (k: 0.05 ) to $54.60 \%$ (k: 0.02 ) in the residues.

Table 3. Dry matter degradability characteristic of feedstuff

\begin{tabular}{lccccc}
\hline \multirow{2}{*}{ Feedstuff } & \multicolumn{4}{c}{ Fraction } & \multirow{2}{*}{ ED (Kp 0.06) } \\
\cline { 2 - 5 } & $\mathrm{a}(\%)$ & $\mathrm{b}(\%)$ & $\mathrm{a}+\mathrm{b}(\%)$ & $\mathrm{c}(/ \mathrm{hr})$ & \\
\hline $\mathrm{Aw}$ & $15.65 \pm 4.11^{\mathrm{a}}$ & $45.95 \pm 1.46^{\mathrm{q}}$ & $61.59 \pm 2.65^{\mathrm{p}}$ & $0.04 \pm 0.02$ & $33.08 \pm 2.83^{\mathrm{p}}$ \\
$\mathrm{dCw}$ & $37.72 \pm 3.78^{\mathrm{b}}$ & $58.58 \pm 1.43^{\mathrm{r}}$ & $96.30 \pm 5.22^{\mathrm{r}}$ & $0.04 \pm 0.02$ & $58.81 \pm 4.83^{\mathrm{q}}$ \\
$\mathrm{dLl}$ & $31.35 \pm 6.47^{\mathrm{b}}$ & $33.28 \pm 4.55^{\mathrm{p}}$ & $64.62 \pm 1.92^{\mathrm{p}}$ & $0.07 \pm 0.01$ & $49.52 \pm 3.18^{\mathrm{q}}$ \\
$\mathrm{Cf}$ & $40.92 \pm 4.26^{\mathrm{b}}$ & $38.33 \pm 3.75^{\mathrm{pq}}$ & $79.25 \pm 0.51^{\mathrm{q}}$ & $0.06 \pm 0.00$ & $59.99 \pm 2.30^{\mathrm{r}}$ \\
\hline
\end{tabular}

A: The water soluble fraction; b: The insoluble but rumen degradable fraction; $c$ : The rate of degradation of the rumen degradable fraction b; ED: Effective degradability; ${ }^{\mathrm{a}, \mathrm{b}}$ Different superscripts at the same column were significant different $(\mathrm{P}<0.05) ;{ }^{\mathrm{p}-\mathrm{r}}$ Different superscripts at same column were high significant different $(\mathrm{P}<0.01)$

\section{Organic matter degradability}

The data of in sacco dry matter degradability (OMD) of respective feedstuff were shown in Figure 2. It can be recognized that OM loss percentage of each feedstuff were highly significant difference within all incubation time. This OMD difference of feedstuff was related to the chemical composition and their degradation characteristic. The content of $\mathrm{OM}$ of $\mathrm{dCw}$ was almost the same if compare to $\mathrm{Aw}(98.4 \%$ vs $97.4 \%)$. Chanjula et al. (2003) reported that ruminal DM and OM disappearance increased with rumen incubation time (0 to $48 \mathrm{~h}$ ). However, the $\mathrm{OMD}$ of $\mathrm{dCw}$ at $24 \mathrm{~h}$ incubation $(62.97 \%)$ was higher than that of Aw (37.59\%). This condition was due to the NDF of Aw (63.4\%) was higher than those on $\mathrm{dCw}(13.4 \%)$. High $\mathrm{NDF}$ level of Aw caused rumen microbes taking longer time to digest Aw. So, Aw can be grouped as low degraded energy source.

During incubation of 3-12 h, the highest of OM loss was at $\mathrm{Cf}(1.03 \% / \mathrm{h})$, followed by $\mathrm{dCw}(0.99 \% / \mathrm{h})$, Aw $(0.92 \% / \mathrm{h})$, and $\mathrm{dLl}(0.79 \% / \mathrm{h})$. At incubation $24-72 \mathrm{~h}$ the OM loss percentage of Aw and $\mathrm{dCw}$ was the same as of $0.18 \% / \mathrm{h}$, followed by $\mathrm{Cf}(0.14 \% / \mathrm{h})$ and $\mathrm{dLl}$ $(0.09 \% / \mathrm{h})$. The decrease of OM loss was related to OM content which can be fermented by microbes. Meanwhile at incubation of 24-72 h, substrates of $\mathrm{dCw}$ and $\mathrm{Cf}$ showed the highest OM loss. This condition reflected that starting at $24 \mathrm{~h}$, this feedstuff was highly degraded and the others were low. 


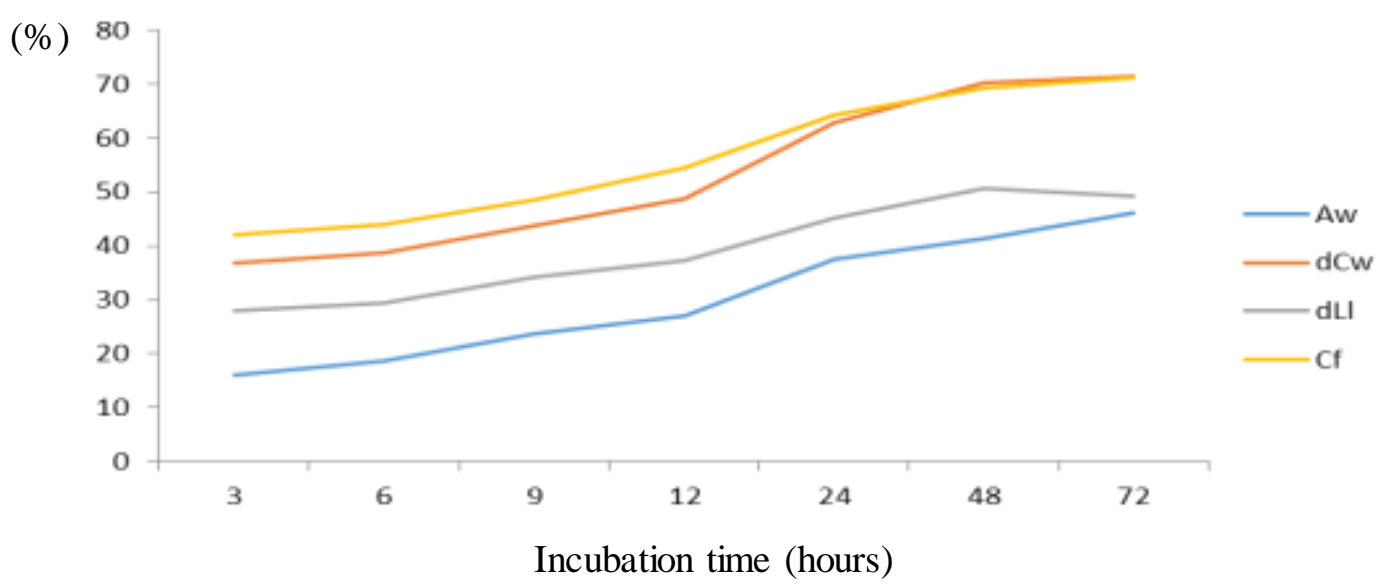

Figure 2. In sacco organic matter degradability (\%) of feedstuff

Table 4. Organic matter loss percentage at two level interval incubation of feedstuff $(\% / \mathrm{h})$

\begin{tabular}{lcc}
\hline \hline \multirow{2}{*}{ Feedstuff } & \multicolumn{2}{c}{ Interval of incubation (h) } \\
\cline { 2 - 3 } & $3-12$ & $24-72$ \\
\hline $\mathrm{Aw}$ & $0.92 \pm 0.17$ & $0.18 \pm 0.11$ \\
$\mathrm{dCw}$ & $0.99 \pm 0.24$ & $0.18 \pm 0.05$ \\
$\mathrm{dL} 1$ & $0.79 \pm 0.13$ & $0.09 \pm 0.01$ \\
$\mathrm{Cf}$ & $1.03 \pm 0.28$ & $0.14 \pm 0.07$ \\
\hline
\end{tabular}

Result on determining OM degradability characteristic of feedstuff was showed in Table 5. The value of solubility (fraction a) of Aw (12.03\%) and dLl (23.60\%) was not different, but they were lower than those on $\mathrm{dCw}$ and $\mathrm{Cf}$. This reflected that $\mathrm{Aw}$ and $\mathrm{dLl}$ were difficult to digest by rumen microbes. Factors that limited the level of solubility and degrading substrates were high fiber content (NDF dan ADF) and it affected the low of fraction $\mathrm{b}$ as well. Meanwhile the value of fraction $\mathrm{c}$ was not different at respective substrates. Data on Table 5 showed that fraction $(\mathrm{a}+\mathrm{b})$ of $\mathrm{Cw}$ was the highest $(83.75 \%)$, followed by $\mathrm{dCw}$ (76.28\%), dLl (56.11\%) and Aw (47.39\%). Maximum degradation of all feedstuff was not optimum, this due to the value of fraction $(a+b)$ of each substrate was higher than those on the OM loss percentage at $72 \mathrm{~h}$ incubation as follows: $\mathrm{Cf}(83.75 \%$ vs $71.16 \%), \mathrm{dCw}(76.28 \%$ vs $71.46 \%)$, LDl (56.11\% vs $49.28 \%$ ), and Aw (47.39\% vs. $46.22 \%$ ). In terms of OMD, Belachew et al (2013) reported ED was found to be the greatest in fruits compared to leaves of the plants. Generally variation of plant parts led to significant differences in chemical composition, $\mathrm{DM}$ and $\mathrm{OM}$ degradability and the degradable parameters.

Table 5. Organic matter degradability characteristic of feedstuff (\%)

\begin{tabular}{lccccc}
\hline \hline \multirow{2}{*}{ Feedstuff } & \multicolumn{4}{c}{ Fraction } & \multirow{2}{*}{ ED (Kp 0.06) } \\
\cline { 2 - 5 } & $\mathrm{a}(\%)$ & $\mathrm{b}(\%)$ & $\mathrm{a}+\mathrm{b}(\%)$ & $\mathrm{c}(\% / \mathrm{h})$ & \\
\hline $\mathrm{Aw}$ & $12.03^{\mathrm{a}} \pm 3.16$ & $35.35^{\mathrm{a}} \pm 1.12$ & $47.39^{\mathrm{a}} \pm 2.03$ & $3.50 \pm 0.02$ & $25.45^{\mathrm{a}} \pm 2.18$ \\
$\mathrm{dCw}$ & $29.88^{\mathrm{ab}} \pm 2.99$ & $46.40^{\mathrm{b}} \pm 1.13$ & $76.28^{\mathrm{ab}} \pm 4.12$ & $3.50 \pm 0.02$ & $46.58^{\mathrm{ab}} \pm 3.82$ \\
$\mathrm{dLl}$ & $23.60^{\mathrm{a}} \pm 3.01$ & $32.52^{\mathrm{a}} \pm 4.67$ & $56.11^{\mathrm{ab}} \pm 7.68$ & $8.50 \pm 0.02$ & $42.44^{\mathrm{ab}} \pm 8.10$ \\
$\mathrm{Cf}$ & $42.42^{\mathrm{b}} \pm 11.57$ & $41.34^{\mathrm{ab}} \pm 5.40$ & $83.75^{\mathrm{b}} \pm 16.96$ & $5.50 \pm 0.01$ & $62.28^{\mathrm{b}} \pm 12.91$ \\
\hline
\end{tabular}

${ }^{\mathrm{a}, \mathrm{b}, \mathrm{c}}$ Different superscript at the same column was significantly different $(\mathrm{P}<0.05)$ 
The effective degradability of each feedstuff showed significant different. The highest $\mathrm{ED}$ was in $\mathrm{Cf}$ (62.28\%), followed by $\mathrm{dCw}$ (46.58\%), $\mathrm{dLl}(42.44 \%)$, and $\mathrm{Aw}(25.45 \%)$. The high of ED of Cf was due to with the high of its OM and CP content which were $91.0 \%$ and $23.0 \%$, respectively. So, the high content of $\mathrm{OM}$ and $\mathrm{CP}$ enhanced the microbial activity for digesting substrates.

\section{CONCLUSION}

The effective dry matter degradability of commercial feed (Cf), dried-Cassava waste $(\mathrm{dCw})$, dried-Leucaena leaves was the same but they were higher than that of Arenga waste (Aw). This condition was also alike with their effective organic matter degradability. It can be concluded that each of feedstuff with its characteristic can be used for complete feed by mixing them with consideration of their in sacco degradability and how they have been classified by degradation characteristics.

\section{REFERENCES}

Belachew Z, Yisehak K, Taye T, Jansens GPJ. 2013. Chemical composition and in sacco ruminal degradation of tropical trees rich in condensed tannins. Czech J Anim Sci. 58:176-192.

Biricik H, Turkmen II, Deniz G, Gulmez BH, Gencoglu H, Bozan B. 2006. Effects of synchronizing starch and protein degradation in rumen on fermentation, nutrient utilization and total tract digestibility in sheep. Ital J Anim Sci. 5:341-348.

Chanjula P, Wanapat M, Wachirapakorn C, Uriyapongson S, Rowlinson P. 2003. Ruminal degradability of tropical feeds and their potential use in ruminant diets. Australas J Anim Sci. 16:211-216.

Ginting SP. 2005. Sinkronisasi degradasi protein dan energi dalam rumen untuk memaksimalkan produksi protein mikrobia. Wartazoa. 15:1-10.

Ikhimioya I, Isa OA, Ikathua UJ, Bamikole MA. 2005. Rumen degradability of dry matter and crude protein in tree leaves and crop residues in humid Nigeria. Pak J Nut. 4:313-320.

McDonald I. 1981. A revised model for estimation of protein degradation in the rumen. J Agri Sci. 96:251-252.

Newman YC, Sollenberger LE, Kunkle WE, Bates DB. 2002. Crude protein fractionation and degradation parameters of limpograss herbage. Agron J. 94:1381-1382.

Osuji PO, Nashlay IV, Khalili H. 1993. Feed evaluation. ILCA. Manual 5. Addis Ababa (Ethiopia): ILCA Addis Ababa. p. 9-14.

Orskov ER. 1982. Protein nutrition in ruminants. London (UK): Academic Press Inc.

Pamungkas D. 2011. Suplementasi sumber energi dan protein dengan laju degradasi berbeda pada pakan basal tumpi jagung dan kulit kopi terhadap kinerja sapi potong [Disertasi]. [Yogyakarta (Indonesia)]: Fakultas Peternakan, Universitas Gadjah Mada.

Soeharto M. 2004. Dukungan teknologi pakan dalam usaha sapi potong berbasis sumber daya lokal. Dalam: Setiadi B, Priyanti A, Handiwirawan E, Diwyanto K, Wijono DB, penyunting. Strategi Pengembangan Sapi Potong dengan Pendekatan Agribisnis dan Berkelanjutan. Prosiding Lokakarya Nasional Sapi Potong. Yogyakarta, 8-9 Oktober 2004. Bogor (Indonesia): Puslitbangnak. hlm. 14-21.

Utomo R, Reksohadiprodjo S, Widyobroto BP, Bachrudin Z, Suhartanto B. 1999. Sinkronisasi degradasi energi dan protein dalam rumen pada ransum basal jerami padi untuk meningkatkan efisiensi kecernaan nutrien sapi potong. Laporan Penelitian Komprehensif HBV. Proyek Pengkajian dan Penelitian Ilmu Pengetahuan Terapan. Yogyakarta (Indonesia): Lemlit UGM. 